\title{
TRADISI MAKEPUNG DALAM PEMERTAHANAN BUDAYA LOKAL DI KABUPATEN JEMBRANA (STUDI KASUS DI DESA KALIAKAH, KECAMATAN NEGARA, KABUPATEN JEMBRANA)
}

\author{
Oleh: \\ I Kade Anggariyana \\ (Dr. I Gusti Ketut Arya Sunu M.Pd dan Drs. Dewa Bagus Sanjaya, M.Si) \\ Jurusan Pendidikan Pancasila dan Kewarganegaraan \\ e-mail: riyana.angga@gmail.com, arya_sunu@yahoo.co.id,gussanjaya14@yahoo.co.id
}

\section{ABSTRAK}

Penelitian ini bertujuan untuk mengetahui: (1) asal mula munculnya tradisi makepung di Desa Kaliakah; (2) pelaksanaan tradisi makepung di Desa Kaliakah; (3) strategi pemertahanan tradisi makepung di Desa Kaliakah; (4) kendala-kendala yang dihadapi dalam pemertahanan tradisi makepung di Desa Kaliakah dan Bagaimana alternatif pemecahannya.

Penelitian ini merupakan penelitian deskriptif kualitatif. Subjek penelitian ditentukan secara purposive, yang terdiri dari; (1) Pemilik Kerbau pepadu di Desa Kaliakah; (2) Prebekel Desa Kaliakah; (3) Pengurus makepung di Desa Kaliakah. Data dikumpulkan dengan menggunakan; (1) metode observasi; (2) metode wawancara; (3) metode dokumentas; (4) metode kepustakaan.

Hasil penelitian ini menunjukan bahwa: (1) tradisi makepung di Desa Kaliakah berawal dari tahapan proses pengolahan tanah sawah menjadi lumpur. Kegiatan makepung di tanah sawah di Desa Kaliakah pertama kali dilakukan sekitar tahun 1930. Tradisi makepung di jalan sawah di Desa Kaliakah berkembang sekitaran tahun 1960 hingga sekarang. (2) tradisi makepung di Desa Kaliakah dilakukan dengan cara meletakan satu pasang kerbau di depan dan satu pasang di belakang dengan jarak $10 \mathrm{~m}$. Jika pasangan kerbau yang berada di depan berjarak lebih dari $10 \mathrm{~m}$ dari pasangan kerbau yang berada di belakang maka pasangan kerbau yang di depan yang menjadi pemenangnya dan jika berjarak kurang dari $10 \mathrm{~m}$, maka pasangan kerbau yang di belakang yang menjadi pemenangnya; (3) strategi pemertahanan tradisi makepung di Desa Kaliakah yaitu; a) menyediakan sarana berupa lintasan makepung, b) setiap tahunnya menyelenggarakan tradisi makepung, c) menggratiskan seluruh biaya dalam tradisi makepung; (4) kendalakendala yang dihadapi dalam pemertahanan tradisi makepung di Desa Kaliakah yaitu; a) masalah modal, b) susahnya mencari bibit-bibit kerbau pepadu, c) sulitnya mencari rumput segar pada musim kemarau. Alternatif pemecahannya yaitu; a) adanya bantuan dana dari Pemerintah kepada para pemilik kerbau pepadu, b) bantuan penyediaan bibit-bibit kerbau pepadu dari pihak Pemerintah, c) mencari dan membeli pakan rumput segar dan pakan alternatif keluar Desa Kaliakah.

Kata Kunci: Tradisi, pemertahanan budaya lokal, makepung. 
This study aims to determine: (1) the origin of the emergence of a tradition makepung in the Kaliakah Village; (2) implementation of the tradition makepung in the Kaliakah Village; (3) retention strategies makepung tradition in the Kaliakah Village; (4) obstacles encountered in preservation makepung tradition in Kaliakah Village and how can alternative solutions.

This research is a qualitative descriptive study. Research subjects are determined by purposive, which consists of; (1) The owner of pepadu buffalo in Kaliakah Village; (2) Prebekel Kaliakah Village; (3) The Board of makepung in Kaliakah Village. Data was collected using; (1) the method of observation; (2) interviews; (3) methods of documentation; (4) methods of literature.

These results indicate that: (1) Makepung tradition in the Kaliakah Village originated from the processing stages of paddy soil into mud using a plow. Makepung activity in paddy field in the Kaliakah Village first performed about 1930. Makepung tradition on the road in the paddy fields in the Kaliakah Village growing from 1960 to the present. (2) Makepung tradition in the Kaliakah Village is done by placing a pair of buffalo in the front and one pair in the back with a distance of $10 \mathrm{~m}$. If couples buffalo who are in front of is more than $10 \mathrm{~m}$ from the couples of buffalo that are behind, the couples buffalo in front is the winner, and if couples of buffalo who are in front is less than $10 \mathrm{~m}$ from the couples of buffalo that were behind, the couples of buffalo in the behind is the winner; (3) preservation strategies makepung tradition in the Village of Kaliakah that is: a) by providing a means of makepung trajectory, b) with annually held makepung tradition, c) eliminate the entire cost of the makepung tradition. (4) the obstacles in preservation makepung tradition in the Kaliakah Village that is: a) the issue of capital, b) hard to find the seeds of pepadu buffalo, c) the difficulty of finding fresh grass to feed pepadu buffalo during the dry season. Alternative solutions that is: a) the concern of the Government in the form of aid funds to the owners of the pepadu buffalo on the eve of the existence of makepung events, b) providing assistance in the form of seeds pepadu buffalo from the Government, c) locate and buy the feed in the form of fresh grass and feed alternatives out Kaliakah Village.

Keywords: tradition, preservation of local culture, makepung

\section{PENDAHULUAN}

Kebudayaan sebagai aktivitas manusia yang melibatkan unsur karsa, rasa dan cipta diibaratkan lingkaran yang tidak mengenal ujung ataupun pangkalnya. Suatu produk budaya dikatakan merupakan awal, dalam waktu yang singkat bisa menjadi pijakan untuk kegiatan budaya yang baru lainnya. Hal ini karena kegiatan kebudayaan berhubungan dengan kondisi yang berhubungan dengan manusia sebagai aktornya maupun alam dan benda sebagai objeknya selalu berubah atau berkembang. Budaya adalah suatu cara hidup yang berkembang dan dimiliki bersama oleh sebuah kelompok orang dan diwariskan dari generasi ke generasi. Budaya dibentuk dari banyak unsur yang rumit, termasuk sistem agama dan politik, adat istiadat, bahasa, perkakas, pakaian, bangunan, dan karya seni. (Purwanto, 2006:26)

Kebudayaan perlu dihimpun karena berpotensi hilang atau musnah yang bisa berarti putusnya rantai sejarah suatu peradaban, hilangnya nilai kearifan, ilmu pengetahuan dan keindahan, serta keunikaannya. Setelah dihimpun kebudayaan juga perlu dirawat untuk menjaga eksistensinya. Tahap berikutnya kebudayaan perlu disebarkan karena, kebudayaan membutuhkan apresiasi dan kritik agar dapat terus berkembang serta berdayaguna. Mempertahankan, memelihara, mengembangkan serta menyempurnakan kebudayaan merupakan kewajiban masyarakat baik dalam arti perorangan, kelompok maupun dalam arti keseluruhan. Ciri khas dan kepribadian suatu bangsa terutama terletak pada kebudayaan yang dimilikinya 
(Soetrisno, 1982: 3).

Indonesia adalah Negara

kepulauan yang terdiri dari ribuan pulau, baik pulau yang berukuran besar maupun kecil. Pulau-pulau tersebut terbentang dari Sabang sampai Merauke. Oleh karena hal tersebut Indonesia mempunyai kekeyaan akan kebudayaan yang lahir dari tradisitradisi masyarakatnya. Masyarakat Indonesia terdiri dari berbagai macam suku, ras, dan agama, Karena kemajemukan masyarakatnya tersebut menciptakan keberagaman budaya yang ada di Indonesia. Kebudayaan tersebut termanifestasikan dalam beragam corak baik itu berupa bahasa, lagu daerah, pakaian adat, makanan tradisonal, tradisi maupun kesenian.

Bali merupakan salah satu Provinsi dari 34 Provinsi di Indonesia. Provinsi Bali terdiri dari pulau Bali, pulau Nusa Penida dan pulau-pulau kecil lainnya memiliki wilayah seluas $5.632,86$ km2. Secara administrasi Provinsi Bali terdiri dari 8 Kabupaten, yaitu Badung, Gianyar, Bangli, Klungkung, Karangasem, Tabanan, Buleleng, Jembrana dan satu Kotamadya Denpasar sebagai pusat Ibukota Provinsi, 55 Kecamatan, 701 Desa/Kelurahan, 1432 Desa Adat/Desa Pekraman dan 3045 Banjar Adat. Walaupun dengan luas wilayah yang terggolong kecil, Bali mempunyai keindahan alam serta kaya akan budaya dan tradisi yang dimiliki di setiap masingmasing Kabupatennya. Itu sebabnya Bali mempunyai ciri khas dan keunikan tersendiri yang membedakannya dengan Provinsi yang lain di Indonesia. Hal tersebutlah yang menjadi daya tarik Pulau Bali, sehingga tidak mengherakan kalau Pulau Bali menjadi salah satu tujuan wisata yang paling banyak dikunjungi baik oleh wisatawan lokal maupun wisatawan dari mancanegara (csgteis, 14 November 2013).

Kabupaten Jembrana sebagai salah satu Kabupaten di Provinsi Bali mempunyai suatu tradisi unik yang merupakan budaya lokal dari masyarakat Kabupaten Jembrana. Tradisi tersebut adalah tradisi balapan kerbau atau yang sering disebut dengan Makepung. Makepung dalam bahasa Indonesia berarti berkejar-kejaran, dimanna dalam tradisi Makepung ini digunakan dua pasang kerbau yang saling berkejarkejaran guna untuk menjadi pemenang. Tradisi ini awalnya muncul dari kegiatan membajak sawah yang dilakukan secara gotong royong oleh para petani selama musim tanam di sawah. Dalam kegiatan membajak tersebut digunakan dua ekor kerbau yang menarik bajak lampit yang ditunggangi oleh seorang joki/sais. Dalam kegiatan gotong royong membajak sawah tersebut terdapat banyak bajak lampit yang masing-masing dtunggangi oleh seorang joki/sais, mulailah timbul rasa untuk saling mengadu kekuatan kerbau merka masing-masing. Hal itulah yang menjadi cikal bakal perlombaan yang dinamakan Makepung.

Tradisi Makepung di sawah ini berkembang sekitar tahun 1930 dan sais/jokinya berpakain ala prajurit Kerajaan di Bali jaman dulu yaitu memekai destar, selendang, selempod, celana panjang tanpa alas kaki dan dipinggang terselip sebilah pedang yang memakai sarung poleng (warna hitam putih). Berselang beberapa lama karena setelah selesai tradisi Makepung di tengah sawah berlumpur para sais/joki selalu kotor dilumuri lumpur, maka tradisi Makepung ini kemudian berkebang menjadi Makepung di jalan yang ada di sawah.

Tradisi Makepung di jalan sawah berkembang mulai tahun 1960 dengan dibentuk organisasi Makepung yang terdiri dari dua kelompok yang diberi Nama "Regu ljo Gading Timur" dengan lambang bendera warna merah dan kelompok "Regu ljo Gading Barat" dengan lambang bendera warna hijau. Sarana yang dipakai bukan lagi bajak lampit melainkan pedati/gerobak dengan ukuran sangat mini yang dihiasi dengan ukiran yang sangat menarik. Para sais/joki berbusana tradisional yaitu memakai destar batik, baju tanganpanjang memakai selempod, memakai celana panjang dan memakai sepatu tetapi tidak menyelipkan pedang pada pinggang.

Makepung selalu rutin dilaksanakan setiap tahunnya, yaitu pada saat para petani selesai panen disawah dan selalu ramai diikuti oleh peserta dari seluruh wilayah Kabupaten Jembrana. 
Pelaksanaan Makepung ini dimulai kisaran bulan Juli sampai Oktober, baik itu berupa latihan, pertandingan persahabatan, perebutan piala Bupati (Bupati cup), maupun perebutan piala Gubernur (Gubernur cup).

Namun akhir-akhir ini tradisi Makepung dirasakan semakin tenggelam digerus oleh perkembangan jaman, ini dapat dilihat dari banyaknya jalan-jalan sawah yang dahulunya digunakan untuk tradisi Makepung kini sudah berubah menjadi jalan yang berbatu dan beraspal, sehingga tidak dapat lagi dapat digunakan untuk melaksanakan tradisi Makepung. Perhatian Pemerintah Provinsi Bali pun mulai berkurang terhadap kelangsungan tradisi Makepung ini. Hal tersebut terlihat dari pelaksanaan ivent Gubernur cup yang biasanya dilaksanakan setiap tahunnya namun dalam lima tahun terakhir ini ivent tersebut sudah tidak dilaksanakan lagi. Padahal peran Pemerintah Provinsi maupun Pemerintah Kabupaten dalam hal ini sangat dibutuhkan agar kelangsungan tradisi Makepung ini dapat terus dipertahankan kelestariannya. Terlebih tradisi Makepung ini merupakan warisan dari nenek moyang yang mempunyai nilainilai luhur yang harus tetap di pertahankan keberadaanya.

\section{METODE PENELITIAN}

Adapun Rancangan penelitian ini menggunakan rancangan penelitian deskriptif kualitatif yaitu penelitian yang menghasilkan data deskriptif berupa katakata tertulis atau lisan dari orang-orang dan pelaku yang diamati. Penelitian deskriptif adalah penelitian yang bermaksud membuat penjabaran (deskripsi) mengenai situasi atau kejadian-kejadian. Metode ini menggambarkan temuan variabel di lapangan yang tidak memerlukan sekala hipotesis. Jadi sifatnya hanya menggambarkan dan menjabarkan temuan yang didapat dilapangan. Penelitian ini bertujuan untuk mendeskripsikan dan menjelaskan tentang bagaimana tradisi Makepung dalam pemertahanan budaya lokal di Kabupaten Jembrana (studi kasus di Desa Kaliakah, Kecamatan Negara, Kabupaten Jembrana).
1. Lokasi Penelitian

Dalam penelitian ini peneliti mengambil lokasi di Desa Kaliakah, Kecamatan Negara, Kabupaten Jembrana. Daerah ini dipilih menjadi lokasi penelitian karena Desa Kaliakah mempuanyai lintasan (track) yang selalu menyelenggarakan tradisi Makepung setiap tahunnya. Di Desa kaliakah juga terdapat banyak masyarakatnya yang memelihara kerpau Pepadu (kerbau untuk Makepung).

2. Subjek Penelitian

Adapun subjek dalam penelitian ini, diantaranya: Pemilik Kerbau Pepadu di Desa Kaliakah, Prebekel Desa Kaliakah dan Pengurus Makepung di Desa Kaliakah

\section{Teknik Pengumpulan Data}

Teknik pengumpulan data pada peneliti ini dilakukan dengan beberapa metode yaitu: metode observasi, metode wawancara, metode pencatatan dokumen dan metode kepustakaan.

1. Teknik Analisis Data

Adapun teknik pengumpulan data yang digunakan dalam penelitian adalah deskriptif kualitatif. Selanjutnya dimana data-data yang diperoleh akan disusun secara sistematis dan selektif sehingga memperoleh suatu kesimpulan umum. Tujuan metode deskriptif kualitatif adalah membuat pencandraan secara sistematis, faktual dan akurat mengenai fakta-fakta dari suatu peristiwa atau gejala tertentu.

\section{HASIL DAN PEMBAHASAN}

\section{Hasil Penelitian}

Berdasarkan hasil wawancara dengan Made Suka selaku pemilik kerbau Pepadu (20 Mei 2014), tradisi Makepung awalnya muncul pada saat para petani melakukan proses melumatkan tanah menjadi lumpur dengan menggunakan alat yang dinamakan bajak lampit. Bajak lampit ditarik oleh dua ekor kerbau dan dikendalikan oleh seorang joki atau juga sering disebut sais. Dalam melakukan proses melumatkan tanah menjadi lumpur tersebut para petani di Desa Kaliakah dahulu selalu bergotong-royong dan saling membantu antara satu dengan yang lainnya. Suatu saat untuk menghilangkan jenuh dalam proses membajak, para joki mulai mempunyai 
keinginan untuk mengadu kekuatan kerbau mereka masing-masing dalam menarik bajak lampit. Ternyata hal tersebut menimbulkan kesenangan di kalangan para petani sehingga dilakukan secara berulang-ulang pada setiap kegiatan membajak sawah. Dari kegiatan inilah awal mula tradisi Makepung di Desa Kaliakah, yaitu Makepung di tanah sawah yang berlumpur.

Di Desa Kaliakah kegiatan Makepung di tanah sawah ini pertama kali dilakukan sekitar tahun 1930. Seiring berjalannya waktu, lama-kelamaan tradisi Makepung di tanah yang berlumpur mengalami pergeseran dan berkembang menjadi Makepung di tanah yang kering. Makepung yang semula dilakukan di sawah bergeser menjadi Makepung yang dilakukan di jalan yang berada di sekitaran sawah. Tradisi Makepung di jalan sawah di Desa Kaliakah berkembang sekitaran tahun 1960 hingga sekarang. Dimana dalam tradisi Makepung ini dibentuk organisasi yang terdiri dari dua kelompok, yaitu ljo Gading Timur dan ljo Gading Barat. Sarana yang digunakan dalam Makepung di jalan sekitar sawah tidak lagi bajak lampit, melaikan menggunakan gerobak kecil yang dihiasi dengan ukiran yang dinamakan cikar (Made Suka, Wawancara 20 Mei 2014).

Berdasarkan hasil wawancara dengan Bapak Armanta selaku pemilik kerbau Pepadu di Desa Kaliakah (20 Mei 2014), Pelaksanaan tradisi Makepung di Desa Kaliakah dimulai dengan melakukan pertemuan (sangkep) yang dihadiri oleh para pemilik kerbau Pepadu dan para pengurus oragnisasi Makepung baik kelompok ljo Gading Timur Maupun kelompok ljo Gading Barat, satu malam sebelum dilakukannya tradisi Makepung. Pertemuan ini bertujuan untuk memberi nomor pada masing-masing pasangan kerbau Pepadu serta mencari lawan yang akan ditandingkan pada saat Makepung nantinya. Setelah semua peserta mendapatkan nomor keesokan harinya para pemilik kerbau dari seluruh Desa di Kabupaten Jembrana berkumpul di sekitaran lintasan Makepung Blatung Cina di Desa Kaliakah dengan membawa kerbau miliknya masing-masing. Kerbau
Pepadu dihias dengan berbagai macam aksesoris agar terlihat menarik, aksesoris yang di pakaikan seperti rumbing, selongsong tanduk, kronongan dan gongsang kaki. Makepung dimulai dengan membacakan nama-nama kerbau berdasarkan nomor urutan msing-masing. Cara memulai melepaskan pasangan kerbau dalam Makepung dilakukan dengan meletakan pasangan kerbau yang satu di depan dan yang satu pasang lagi di belakang dengan jarak $10 \mathrm{~m}$. Tradisi Makepung mempunyai aturan yang terbilang unik, karena lintasannya yang berbentuk huruf $U$ jadi peraturannya adalah pergi dan pulang. Kerbau yang di lepaskan pada saat garis start kemudian di diberhentikan di tempat pemberhentian. Pada saat kerbau dilepaskan dari garis start atau pada saat pergi menuju tempat pemberhentian itu lebih sebagai pemanasan dan para joki atau sais biasanya tidak begitu sering memukul kerbaunya dengan tungked (tongkat penyalin berpaku untuk memukul kerbau saat Makepung). Kemudian kerbau tersebut dilepaskan kembali dari tempat pemberhentian ke garis start awal. Disinilah penilain baru dilakukan yaitu dari tempat pemberhentian menuju start awal. Biasanya saat inilah para joki atau sais barulah secara habis-habisan memukuli pasangan kerbau dengan tungked dari penyalin berpaku, agar pasangan kerbau yang dikendalikannya tersebut mampu berlari dengan sekencang-kencangnya. Jika pasangan kerbau yang berada didepan berjarak lebih dari $10 \mathrm{~m}$ dari pasangan kerbau yang berada di belakangnya maka pasangan kerbau yang di depanlah yang menjadi pemenangnya, dan jika pasangan kerbau yang berada di depan berjarak kurang dari $10 \mathrm{~m}$ dari pasangan kerbau yang berada dibelakangnya maka pasangan kerbau yang di belakanglah yang menjadi pemenangnya. Jadi dalam tradisi Makepung garis start awal juga sekaligus sebagai garis finish (Armanta, Wawancara 20 Mei 2014).

Adapun strategi yang dilakuakan Desa Kaliakah untuk mempertahankan tradisi Makepung adalah: (1) dengan cara menyediakan sarana seperti lintasan Makepung yang baik serta dapat 
digunakan baik dalam ivent Makepung maupun tempat latihan bagi kerbaukerbau Pepadu yang akan diikut sertakan dalam tradisi Makepung nantinya (Made Bagiarta, Wawancara 26 Mei 2014). (2) dengan menyelenggarakan tradisi Makepung ini setiap tahunnya. Dimana Desa kaliakah merupakan salah satu Desa yang selalu menjadi tuan rumah dalam pelaksanaan tradisi Makepung. Dengan setiap tahunnya Desa Kaliakah selalu melaksanakan tradisi Makepung, secara langsung maupun tidak langsung akan dapat menjaga dan melestarikan keberlangsungan dari tradisi Makepung ini, sehingga nantinya akan terus dapat terus berlangsung dari generasi ke generasi (Made Suka, Wawancara $20 \mathrm{Mei}$ 2014). (3) Desa Kaliakah juga menggratiskan atau tidak mengenakan biaya-biaya apapun menyangkut perlombaan dalam tradisi Makepung. Dengan menggratiskan seluruh biaya dalam kegiatan Makepung di Desa Kaliakah. Diharapkan akan membuat para pemilik kerbau Pepadu menjadi semakin semangat dalam mengikuti setiap ivent Makepung (Bandi Astawa, Wawancara 25 Mei 2014).

Berdasarkan hasil wawancara dengan Bapak Agiasa (22 Mei 2014), adapun Kendala-Kendala Yang Dihadapi Dalam Pemertahanan Tradisi Makepung Di Desa Kaliakah yaitu: (1) masalah modal, modal disini baik dalam pengadaan/pembelian kerbau Pepadu maupun pemeliharaannya. Dimana untuk membeli dan memelihara kerbau Pepadu dibutuhkan biaya yang sangat besar. Itu disebabkan karena harga kerbau Pepadu jauh lebih mahal dibandingkan dengan kerbau biasa. Belum lagi untuk membeli atau membuat alat-alat yang digunakan dalam tradisi Makepung seperti cikar, uge, cagak, kronongan dan lain-lain itu membutuhkan biaya yang besar. (2) susahnya mencari bibit-bibit kerbau Pepadu yang akan digunakan untuk tradisi Makepung. Dimana bibit-bibit kerbau Pepadu yang baik untuk Makepung itu sudah sangat jarang ditemukan di Bali. Sehingga tidak jarang para pecinta Makepung biasanya harus mencari dan mendatangkan bibit kerbau yang baik dan berkualitas dari luar pulau
Bali. (3) terbatas dan sulitnya mencari rumput segar pada saat musim kemarau. Meskipun Desa Kaliakah dikenal sebagai Desa yang subur, tetapi tetap saja pada saat musim kemarau dating, para pemilik kerbau Pepadu sangat sulit mendapatkan rumput segar yang dijadikan sebagai pakan kerbau mereka. Pakan berupa rumput gajah dan rumput tegalan tidak lagi tersedia, karena rumput tersebut mongering dan tidak tumbuh lagi pada saat musim kemarau.

Adapun Alternatif pemecahannya menurut Bapak Agiasa yaitu: (1) dengan adanya kepedulian Pemerintah berupa adanya bantuan dana kepada para pemilik kerbau Pepadu pada saat menjelang adanya ivent-ivent Makepung. Adanya bantuan dari pemerintah tersebut diharapkan dapat memperingan beban para pemilik kerbau Pepadu sehingga tiadak pusing lagi memikirkan biaya-biaya lain seperti biaya transportasi dan konsumsi dalam setiap mengikuti tradisi Makepung. (2) dengan adanya bantuan berupa penyediaan bibit-bibit kerbau Pepadu dari pihak Pemerintah. Agar para pecinta Makepung di Desa Kaliakah tidak kesulitan lagi dalam mencari bibit-bibit kerbau yang akan dijadikan sebagai kerbau Pepadu. Sehingga para pecinta Makepung tidak perlu repot-repot lagi mencari dan mendatangkan bibit-bibit kerbau Pepadu dari luar Pulau Bali. (3) dengan mencari dan membeli pakan berupa rumput segar dan pakan alternatif keluar Desa Kalikah, misalnya membeli ke daerah Desa Yeh Mbang, Tegal cangkring dan Desa-desa lain yang masih memiliki rumput segar ataupun pakan alternatif berupa pohon jagung yang dapat diberikan sebagai pakan untuk kerbau Pepadu.

Selain ketiga kendala tersebut penyebab menurunnya pelaksanaan tradisi Makepung di Desa Kaliakah juga tidak terlepas dari menurunnya kualitas dan kuantitas dari tradisi Makepung itu sendiri. Dimana dari segi kualitas perlu dilakukannya pengarahan-pengarahan kepada para masyarakat Desa Kalikah agar tidak terlalu menuntut (pamrih) terlalu banyak dari pelaksanaan tradisi Makepung ini. Dalam hal ini pembenahan moral perlu dilakukan kepada masyarakat 
Desa Kaliakah, karena dalam mengikuti tradisi Makepung ini bukan hanya untuk mengejar materi semata melainkan untuk melestarikan suatu warisan budaya lokal yang mempunyai nilai-nilai luhur dari para pendahulu kita. Dimana dalam pelaksanaan tradisi Makepung ini akan dapat menciptakan rasa kekeluargaan, mempererat hubungan antar masyarakat, dan memupuk rasa kesetiakawanan diantara masyarakat Desa Kaliakah, sehingga dapat berperan positif dalam mengurangi ataupun menyelesaikan terjadinya konflik. Dalam tradisi Makepung juga terkandung aspek religius yaitu rasa trima kasih dan wujud syukur terhadap karunia yang tuhan Yang Maha Esa.

Dari segi kuantitas, pelaksanaan tradisi Makepung di Desa Kaliakah mengalami penurunan. Hal tersebut nampak dari event Gubernur Cup yang sudah tidak lagi diadakan dalam lima tahun terakhir ini. Penurunan kuantitas tersebut tentu akan mempengaruhi dari eksistensi tradisi Makepung itu sendiri. Oleh karena itu untuk meningkatkan kuantitas dari pelaksanaan tradisi Makepung sekarang ini ivent Gubernur Cup sudah digantikan dengan ivent yang diberi nama Jembrana Cup. Disini Desa Kaliakah merupakan Desa yang ikut berperan dengan adanya ivent berupa Jembrana Cup ini. Itu karena baik secara langsung maupun tidak langsung dengan adanya lintasan Makepung di Desa Kaliakah akan dapat mendukung terselenggaranya ivent Makepung Jembrana Cup. Dengan ditambahnya kuantitas ivent Makepung berupa ivent Makepung Jembrana Cup. tentunya para pecinta Makepung akan semakin termotivasi untuk mempertahankan keberlangsungan dari tradisi Makepung ini. Oleh karena itu diharapkan kelestarian dari tradisi Makepung ini dapat terus terjaga dan bertahan untuk kedepannya, baik di Desa Kaliakah pada khususnya maupun Kabupaten Jembrana pada umumnya (Agiasa, Wawancara $22 \mathrm{Mei}$ 2014).

\section{Pembahasan}

Menurut Mursal Esten (1999: 54) tradisi adalah produk dari suatu masyarakat tradisional yang terbentuk melalui proses yang panjang, tradisi terbentuk dari kebiasaan turun temurun sekelompok masyarakat berdasarkan nilai budaya kelompok yang bersangkutan.

Hal tersebut dapat dibuktikan kebenarannya, seperti halnya pada tradisi Makepung yang diwariskan secara turun temurun dari tahun 1930 sampai sekarang. Berdasarkan hasil wawancara dengan Made Suka selaku pemilik kerbau Pepadu (20 Mei 2014), dimana tradisi Makepung awalnya muncul pada saat para petani melakukan proses melumatkan tanah menjadi lumpur dengan menggunakan alat yang dinamakan bajak lampit. Bajak lampit ditarik oleh dua ekor kerbau dan dikendalikan oleh seorang joki atau juga sering disebut sais. Suatu saat untuk menghilangkan jenuh dalam proses membajak para joki mulai mempunyai keinginan untuk mengadu kekuatan kerbau mereka masing-masing dalam menarik bajak lampit. Dari kegiatan inilah awal mula tradisi Makepung di Desa Kaliakah, yaitu Makepung di tanah sawah yang berlumpur. Di Desa Kaliakah kegiatan Makepung di tanah sawah pertama kali dilakukan sekitar tahun 1930. Seiring berjalannya waktu, lamakelamaan tradisi Makepung di tanah yang berlumpur mengalami pergeseran dan berkembang menjadi Makepung yang dilakukan di jalan yang berada di sekitaran sawah. Tradisi Makepung di jalan sawah di Desa Kaliakah berkembang sekitaran tahun 1960 hingga sekarang. Dimana dalam tradisi Makepung ini dibentuk organisasi yang terdiri dari dua kelompok, yaitu ljo Gading Timur dan ljo Gading Barat.

Menurut pandangan Jan Vasinan sebagaimana dikutip oleh Rupertus, (2010:9) "tradisi adalah kesaksian lisan yang disampaikan secara verbal dari satu generasi ke generasi berikutnya". Adapun aspek-aspek yang terkandung dalam tradisi lisan yaitu aspek sejarah, nilai-nilai moral, keagamaan, adat istiadat, pribahasa, nyanyian, dan mantra. Pmeliharaan nilai-nilai, etika, pranata, tata bahasa, religi, dan keharmonisan hidup sering dilakukan dengan memeanfaatkan tradisi.

Hal tersebut dapat dibuktikan kebenarannya, berdasarkan hasil 
wawancara dengan Armanta selaku pemilik kerbau Pepadu (20 Mei 2014), pelaksanaan tradisi Makepung di Desa Kaliakah dimulai dengan melakukan pertemuan (sangkep) yang dihadiri oleh para pemilik kerbau Pepadu dan para pengurus oragnisasi Makepung baik kelompok ljo Gading Timur Maupun kelompok ljo Gading Barat, satu malam sebelum dilakukannya tradisi Makepung. Pertemuan ini bertujuan untuk memberi nomor pada masing-masing pasangan kerbau Pepadu serta mencari lawan yang akan ditandingkan pada saat Makepung nantinya. Makepung dimulai dengan membacakan nama-nama kerbau berdasarkan nomor urutan msing-masing. Cara memulai melepaskan pasangan kerbau dalam Makepung dilakukan dengan meletakan pasangan kerbau yang satu di depan dan yang satu pasang lagi di belakang dengan jarak $10 \mathrm{~m}$. Kerbau yang di lepaskan pada saat garis start kemudian di diberhentikan di tempat pemberhentian. Pada saat kerbau dilepaskan dari garis start atau pada saat pergi menuju tempat pemberhentian itu lebih sebagai pemanasan dan para joki atau sais biasanya tidak begitu sering memukul kerbaunya dengan tungked (tongkat penyalin berpaku untuk memukul kerbau saat Makepung). Kemudian kerbau tersebut dilepaskan kembali dari tempat pemberhentian ke garis start awal. Disinilah penilain baru dilakukan yaitu dari tempat pemberhentian menuju start awal. Jika pasangan kerbau yang berada didepan berjarak lebih dari $10 \mathrm{~m}$ dari pasangan kerbau yang berada di belakangnya maka pasangan kerbau yang di depanlah yang menjadi pemenangnya, dan jika pasangan kerbau yang berada di depan berjarak kurang dari $10 \mathrm{~m}$ dari pasangan kerbau yang berada dibelakangnya maka pasangan kerbau yang di belakanglah yang menjadi pemenangnya.

Seperti pandangan Hebding dan Glick, (1992) yang dikutip oleh Sudiarta, (2011:12) menguraikan bahwa kebudayaan dapat dilihat secara material maupun non material. Kebudayaan material tampil dalam objek material yang dihasilkan, kemudian yang digunakan manusia. Misalnya saja dari alat-alat yang paling sederhana, seperti: asesoris perhiasan tangan, leher dan telinga, alat rumah tangga dan pakaian. Sebaliknya budaya non material adalah unsur-unsur dimaksud dalam konsep norma-norma, nilai-nilai, kepercayaan atau keyakinan, serta bahasa.

Hal tersebut dapat dibuktikan kebenarannya, berdasarkan atas hasil wawancara dengan Agiasa (22 Mei 2014) dimana selain menggunakan kerbau Pepadu, juga terdapat beberapa alat-alat yang digunakan oleh pemilik kerbau Pepadu di Desa Kaliakah dalam mengikuti tradisi Makepung, yaitu berupa cikar, uge, cagak, kronongan, gongsang, tungked, sarung tanduk serta rumbing. Masyarakat Desa Kaliakah yang memiliki kerbau Pepadu biasanya melakukan latihan (nguruk) pada setiap hari minggu, mulai dari bulan Mei di lintasan Makepung Blatung cina, yaitu lintasan Makepung kebanggaan Masyarakat Desa Kaliakah. Kegiatan latihan ini selalu rutin dilakukan setiap hari minggu, hal ini bertujuan untuk mengetahui dan melatih kemampuan kerbau Pepadu sebelum di ikutkan dalam ivent Makepung. Dimana biasanya kerbau yang sudah sering dilatih akan lebih terbiasa dalam menghadapi orang banyak, sehingga mental kerbau tersebut akan semakin baik untuk di ikutkan dalam Makepung.

Suatu kebudayaan tetap dipertahankan/dilestarikan oleh suatu masyarakat, dalam hal ini adalah tradisitradisi lokal yang ada dalam masyarakat yang berlangsung secara turun temurun yang diwariskan oleh nenek moyang terutama yang memiliki keunikan dan nilai-nilai sosial didalam masyarakat. Tradisi atau kebiasaan disebut sebagai tata kelakuan yang merupakan suatu wujud yang ideal dari pada kebudayaan yang berperan sebagai tingkah laku.

Hal tersebut dapat dibuktikan kebenarannya, berdasarkan atas hasil wawancara dengan Bapak Made Bagiarta selaku Prebekel Desa Kaliakah (26 Mei 2014). Adapun strategi yang dilakuakan Desa Kaliakah untuk mempertahankan tradisi Makepung adalah

1. Dengan cara menyediakan sarana seperti lintasan Makepung yang baik serta dapat digunakan baik dalam ivent 
Makepung maupun tempat latihan bagi kerbau-kerbau Pepadu yang akan diikut sertakan dalam tradisi Makepung nantinya.

2. Dengan menyelenggarakan tradisi Makepung ini setiap tahunnya. Dimana Desa kaliakah merupakan salah satu Desa yang selalu menjadi tuan rumah dalam pelaksanaan tradisi Makepung. Dengan setiap tahunnya Desa Kaliakah selalu melaksanakan tradisi Makepung, secara langsung maupun tidak langsung akan dapat menjaga dan melestarikan keberlangsungan dari tradisi Makepung ini, sehingga nantinya akan terus dapat terus berlangsung dari generasi ke generasi.

3. Dengan menggratiskan atau tidak mengenakan biaya-biaya apapun menyangkut perlombaan dalam tradisi Makepung. Dengan menggratiskan seluruh biaya dalam kegiatan Makepung di Desa Kaliakah. Diharapkan akan membuat para pemilik kerbau Pepadu menjadi semakin semangat dalam mengikuti setiap ivent Makepung.

Dalam mempertahankan suatu tradisi pasti akan terdapat kendalakendala yang akan dihadapi. Dari kendala-kendala tersebut akan dicari bagaimana alternatif pemecahannya guna dapat bertahannya suatu tradisi tersebut.

Hal tersebut dapat dibuktikan kebenarannya, seperti halnya dalam mempertahankan tradisi Makepung. Dimana berdasarkan hasil wawancara dengan Agiasa selaku pengurus Makepung di Desa Kaliakah (22 Mei 2014), bahwa kendala-kendala yang dihadapi oleh para pemilik kerbau Pepadu dalam mempertahankan tradisi Makepung di Desa Kaliakah yaitu:

1. Masalah modal, modal disini baik dalam pengadaan/pembelian kerbau Pepadu maupun pemeliharaannya. Dimana untuk membeli dan memelihara kerbau Pepadu dibutuhkan biaya yang sangat besar. Itu disebabkan karena harga kerbau Pepadu jauh lebih mahal dibandingkan dengan kerbau biasa. Belum lagi untuk membeli atau membuat alat-alat yang digunakan dalam tradisi Makepung seperti cikar, uge, cagak, kronongan dan lain-lain itu membutuhkan biaya yang besar.

2. Susahnya mencari bibit-bibit kerbau Pepadu yang akan digunakan untuk tradisi Makepung. Dimana bibit-bibit kerbau Pepadu yang baik untuk Makepung itu sudah sangat jarang ditemukan di Bali. Sehingga tidak jarang para pecinta Makepung biasanya harus mencari dan mendatangkan bibit kerbau yang baik dan berkualitas dari luar pulau Bali.

3. Terbatas dan sulitnya mencari rumput segar pada saat musim kemarau. Meskipun Desa Kaliakah dikenal sebagai Desa yang subur, tetapi tetap saja pada saat musim kemarau dating, para pemilik kerbau Pepadu sangat sulit mendapatkan rumput segar yang dijadikan sebagai pakan kerbau mereka. Pakan berupa rumput gajah dan rumput tegalan tidak lagi tersedia, karena rumput tersebut mongering dan tidak tumbuh lagi pada saat musim kemarau.

Alternatif pemecahannya yaitu:

1. Dengan adanya kepedulian Pemerintah berupa adanya bantuan dana kepada para pemilik kerbau Pepadu pada saat menjelang adanya ivent-ivent Makepung. Adanya bantuan dari pemerintah tersebut diharapkan dapat memperingan beban para pemilik kerbau Pepadu sehingga tiadak pusing lagi memikirkan biaya-biaya lain seperti biaya transportasi dan konsumsi dalam setiap mengikuti tradisi Makepung.

2. Dengan adanya bantuan berupa penyediaan bibit-bibit kerbau Pepadu dari pihak Pemerintah. Agar para pecinta Makepung di Desa Kaliakah tidak kesulitan lagi dalam mencari bibit-bibit kerbau yang akan dijadikan sebagai kerbau Pepadu. Sehingga para pecinta Makepung tidak perlu repot-repot lagi mencari dan mendatangkan bibit-bibit kerbau Pepadu dari luar Pulau Bali.

3. Dengan mencari dan membeli pakan berupa rumput segar dan pakan alternatif keluar Desa Kalikah, misalnya membeli ke daerah Desa Yeh Mbang, Tegal cangkring dan 
Desa-desa lain yang masih memiliki rumput segar ataupun pakan alternatif berupa pohon jagung yang dapat diberikan sebagai pakan untuk kerbau Pepadu.

Selain ketiga kendala tersebut penyebab menurunnya pelaksanaan tradisi Makepung di Desa Kaliakah juga tidak terlepas dari menurunnya kualitas dan kuantitas dari tradisi Makepung itu sendiri. Dimana dari segi kualitas perlu dilakukannya pengarahan-pengarahan kepada para masyarakat Desa Kalikah agar tidak terlalu menuntut (pamrih) terlalu banyak dari pelaksanaan tradisi Makepung ini. Dalam hal ini pembenahan moral perlu dilakukan kepada masyarakat Desa Kaliakah, karena dalam mengikuti tradisi Makepung ini bukan hanya untuk mengejar materi semata melainkan untuk melestarikan suatu warisan budaya lokal yang mempunyai nilai-nilai luhur dari para pendahulu kita. Dimana dalam pelaksanaan tradisi Makepung ini akan dapat menciptakan rasa kekeluargaan, mempererat hubungan antar masyarakat, dan memupuk rasa kesetiakawanan diantara masyarakat Desa Kaliakah, sehingga dapat berperan positif dalam mengurangi ataupun menyelesaikan terjadinya konflik. Dalam tradisi Makepung juga terkandung aspek religius yaitu rasa trima kasih dan wujud syukur terhadap karunia yang tuhan Yang Maha Esa.

Dari segi kuantitas, pelaksanaan tradisi Makepung di Desa Kaliakah mengalami penurunan. Hal tersebut nampak dari event Gubernur Cup yang sudah tidak lagi diadakan dalam lima tahun terakhir ini. Penurunan kuantitas tersebut tentu akan mempengaruhi dari eksistensi tradisi Makepung itu sendiri. Oleh karena itu untuk meningkatkan kuantitas dari pelaksanaan tradisi Makepung sekarang ini ivent Gubernur Cup sudah digantikan dengan ivent yang diberi nama Jembrana Cup. Disini Desa Kaliakah merupakan Desa yang ikut berperan dengan adanya ivent berupa Jembrana Cup ini. Itu karena baik secara langsung maupun tidak langsung dengan adanya lintasan Makepung di Desa Kaliakah akan dapat mendukung terselenggaranya ivent Makepung
Jembrana Cup. Dengan ditambahnya kuantitas ivent Makepung berupa ivent Makepung Jembrana Cup. tentunya para pecinta Makepung akan semakin termotivasi untuk mempertahankan keberlangsungan dari tradisi Makepung ini. Oleh karena itu diharapkan kelestarian dari tradisi Makepung ini dapat terus terjaga dan bertahan untuk kedepannya, baik di Desa Kaliakah pada khususnya maupun Kabupaten Jembrana pada umumnya (Agiasa, Wawancara 22 Mei 2014).

\section{PENUTUP}

\section{Kesimpulan}

sesuai

dengan uraian

pembahasan pokok permasalahan tersebut diatas, maka dapatlah diambil pokok-pokok pikiran yang merupakan simpulan sebagai akhir dari materi yang diuraikan pada skripsi ini adalah sebagai berikut:

1. Tradis Makepung awalnya muncul pada saat para petani melakukan proses melumatkan tanah menjadi lumpur dengan menggunakan alat yang dinamakan bajak lampit. Di Desa Kaliakah kegiatan Makepung di tanah sawah ini pertama kali dilakukan sekitar tahun 1930. Tradisi Makepung di jalan sawah di Desa Kaliakah berkembang sekitaran tahun 1960 hingga sekarang. Dimana dalam tradisi Makepung ini dibentuk organisasi yang terdiri dari dua kelompok, yaitu ljo Gading Timur dan ljo Gading Barat.

2. Pelaksanaan tradisi Makepung di Desa Kaliakah yaitu dimulai dengan melakukan pertemuan (sangkep) yang dihadiri oleh para pemilik kerbau Pepadu (kerbau untuk Makepung) dan para pengurus oragnisasi Makepung baik kelompok ljo Gading Timur Maupun kelompok ljo Gading Barat, satu malam sebelum dilakukannya tradisi Makepung. Pertemuan ini bertujuan untuk memberi nomor pada masing-masing pasangan kerbau Pepadu serta mencari lawan yang akan ditandingkan pada saat Makepung nantinya. Cara memulai melepaskan pasangan kerbau dalam Makepung dilakukan dengan meletakan pasangan kerbau yang satu di depan dan yang 
satu pasang lagi di belakang dengan jarak $10 \mathrm{~m}$. Jika pasangan kerbau yang berada didepan berjarak lebih dari 10 $\mathrm{m}$ dari pasangan kerbau yang berada di belakangnya maka pasangan kerbau yang di depanlah yang menjadi pemenangnya, dan jika pasangan kerbau yang berada di depan berjarak kurang dari $10 \mathrm{~m}$ dari pasangan kerbau yang berada dibelakangnya maka pasangan kerbau yang di belakanglah yang menjadi pemenangnya.

3. Strategi Pemertahanan Tradisi Makepung Di Desa Kaliakah yaitu:

- Dengan cara menyediakan sarana seperti lintasan Makepung yang baik serta dapat digunakan baik dalam ivent Makepung maupun tempat latihan bagi kerbau-kerbau Pepadu yang akan diikut sertakan dalam tradisi Makepung nantinya

- Dengan menyelenggarakan tradisi Makepung ini setiap tahunnya

- Dengan menggratiskan atau tidak mengenakan biaya-biaya apapun menyangkut perlombaan dalam tradisi Makepung.

4. Kendala-Kendala Yang Dihadapi Dalam Pemertahanan Tradisi Makepung Di Desa Kaliakah yaitu:

1. Masalah modal, modal disini baik dalam pembelian kerbau Pepadu maupun dalam pemeliharaannya. Dimana untuk membeli dan memelihara kerbau Pepadu dibutuhkan biaya yang sangat besar.

2. Susahnya mencari bibit-bibit kerbau Pepadu yang akan digunakan untuk tradisi Makepung.

3. Terbatas dan sulitnya mencari rumput segar pada saat musim kemarau.

Alternatif pemecahannya yaitu:

1. Kepedulian Pemerintah berupa adanya bantuan dana kepada para pemilik kerbau Pepadu pada saat menjelang adanya ivent-ivent Makepung.

2. Adanya bantuan berupa penyediaan bibit-bibit kerbau Pepadu dari pihak Pemerintah.

3. Dengan mencari dan membeli pakan berupa rumput segar dan pakan alternatif keluar Desa
Kalikah.

Selain ketiga kendala tersebut penyebab menurunnya pelaksanaan tradisi Makepung di Desa Kaliakah juga tidak terlepas dari menurunnya kualitas dan kuantitas dari tradisi Makepung itu sendiri.

\section{Saran}

Berdasarkan temuan-temuan dalam penelitian ini, peneliti dapat menyampaikan beberapa saran untuk langkah-langkah dalam pemertahanan tradisi Makepung di Desa Kaliakah, Kecamatan Negara, Kabupaten Jembrana ini adalah sebagai berikut:

1. Diharapkan kepada generasi muda untuk terus menjaga dan melestarikan tradisi Makepung, karena tradisi Makepung merupakan tradisi khas masyarakat Jembrana yang merupakan warisan turun temurun yang harus dipertahankan agar tidak hilang begitu saja dimakan oleh perkembangan jaman.

2. Bagi Prebekel Desa Kaliakah diharapkan agar mengeluarkan kebijakan-kebijakan terkait dengan kemudahan dalam melaksanakan tradisi Makepung di Desa Kaliakah.

3. Bagi para pemilik kerbau Pepadu diharapkan agar selalu ikut dan menyemarakan setiap ivent Makepung, agar tradisi Makepung selalu terjaga eksistensinya sehingga tradisi ini dapat trus berlangsung kedepannya.

4. Diharapkan kepada Pemerintah, baik Kabupaten maupun Provinsi agar memberi perhatian lebih terhadap tradisi Makepung, karena dukungan pemerintah disini sangat penting demi kelestarian dan kelangsungan tradisi ini.

5. Diharapkan kepada para pengurus Makepung di Desa Kaliakah agar lebih berperan aktif dalam melestarikan tradisi Makepung, karena pengurus Makepung disini berperan untuk mengatur bagaimana kelangsungan tradisi Makepung untuk kedepannya.

\section{DAFTAR PUSTAKA}

Andrew Aditya Cahyadinata, I Putu, "Perspektif Sosio-Budayadan Religius Terhadap Tradisi Omed-Omedan Di 
Banjar Kaja, Kelurahan Sesetan, Kota Denpasar, Bali". Skripsi (Tidak Diterbitkan). Jurusan Pendidikan Pancasila dan Kewarganegaraan. Undiksha Singaraja

Berita Bali. 2013, 12 April. "Tadisi Makepung Wajib dihidupkan". Tersedia Pada http://www.beritabali.com/index.php/p age/berita/jbr/detail/2013/04/12/Tradis i-Makepung-Wajib-Dihidupkan-

Kembali/201107022425 (diakses tanggal 25 Februari 2014)

Bungin Burhan. 2003. Metodologi Penelitian Kualitatif. Jakarta : PT Raja Grafindo

Csgteis. 2013, 14 November. "Sekilas Bali". Tersedia pada http://csgteis.unud.ac.id/sekilas-bali/ (diakses tanggal 14 Februari 2014)

Dian Pratiwi, Ni Luh Gede Made, 2010. "Tradisi Makotekdi Desa Munggu, Kecamatan Mengwi, Kabupaten Badung Bali". Skripsi (tidak diterbitkan). Jurusan Pendidikan Sejarah. Undiksha Singaraja

Djoko Purwanto. 2006. Komunikasi Bisnis. Jakarta: Erlangga

Endrone Blogspot. 2012. "Makepung Karapan Sapi Bali". Tersedia Pada http://endrone.blogspot.com/2012/0 4/makepung-kerapan-sapi-bali.html\# (diakses tanggal 25 Februari 2014)

Esten Mursal. 1998 . Kajian Transformasi Budaya. Bandung: Percetakan Angkasa

1999. Desentralisasi Kebudayaan. Bandung: Percetakan Angkasa

Juniarta, I Made. 2013. Perkawinan Dibawah Umur Ditinjau Dari Hokum Adat Bali Di Desa Kamasan, Kecamatan Kelungkung, Kabupaten Klungkung (Studi Komparasi Hukum Adat Bali Dengan Hukum Nasional). Skripsi (tidak diterbitkan). Jurusan Pendidikan Pancasila dan Kewarganegaraan. Undiksha Singaraja

KOMPAS.com, 2013, 15 Mei. “ Makepung Adu Balap Kerbau di Jembrana" Tersedia

Padahttp://travel.kompas.com/read/ 2013/05/15/09211642/Makepung.Ad
u.Balap.Kerbau.di.Jembrana

(diakses tanggal 25 Februari 2014)

Koentjaraningrat. 1990. Beberapa Pokok Antropologi Sosial. Jakarta : Dian Rakyat

Made Lestari Dewi, Ida Ayu, 2013. Implikasi Perkawinan Beda Kasta Dalam Perspektif Hukum, SosialBudaya Dan Religius Di Banjar Brahmana Bukit, Kecamatan Bangli, Kabupaten Bangli. Skripsi (tidak diterbitkan). Jurusan Pendidikan Pancasila dan Kewarganegaraan. Undiksha Singaraja

Miles MB dan AM Huberman. Qualitative Data Analysis. A Sourcebook of New Metods. SAGE Beferly Hills

Mudana, I Wayan. 2009. Buku Ajar Ilmu Budaya Dasar. Singaraja : Penerbit Undiksha

Moelong. Lexy, J. 2000. Metodologi Penelitian Kualitatif. Bandung: Remaja Rosdakarya

Narbuko, Cholid dan H. Abu Achmadi. 2005. Metodologi Penelitian. Cetakan VIII. Bandung : PT Remaja Rosdakarya. Usaha Nasional

Ndraha, Talizituhu. 1997. Budaya Organisasi. Jakarta : PT Rineka Cipta

Pemkab Jembrana. 2012. "Semasih Ada Jembrana Makepung Tetap Ada". Tersedia Pada http://www.jembranakab.go.id/index. php? module $=$ detailberita\&id $=1782$ (diakses tanggal 25 Februari 2014)

Rupertus Agus Fitrian M. 2010. Trdisi adat magebeg-gebegan di desa tukad mungga, kecamatan buleleng, kabupaten buleleng (study etnografi tentangnilai-nilai yang terkandung dalam tradisi adat magebeggebegan. Skripsi (Tidak Diterbitkan). Jurusan Pendidikan Pancasila dan Kewarganegaraan. Undiksha Singaraja

Soelaeman, M. Munandar. 2000. IImu Budaya Dasar Suatu pengantar. Bandung : PT Refika Aditama

Suardiasa. Jumat 11 Januari 2013. "Mekepung". Tersedia pada http://suardiasa89.blogspot.com/201 3/01/mekepung.html (diakses tanggal 26 Februari 2014)

Sudiarta, I Gede. 2001 Eksistensi Tradisi 
Metuakan ditengah-tengah

Dinamika Modernisasi di Desa

Pakraman Sekar Gunung

Kecamatan Karangasem Kabupaten

Karangasem-Bali. Skripsi (Tidak

Diterbitkan). Jurusan Pendidikan

Pancasila Kewarganegaraan,

UNDIKSHA Singaraja

Soerjono Soekanto, Sulaeman Tanek.

1987. Hukum Adat Indonesia.

Yogyakarta: Liberty

Soetrisno. 1982. Welfare State dan Welfare Society dalam Ekonomi Pancasila. Yogyakarta: Universitas Gajah Mada

Sztompka, Piotr. 1993. Sosiologi Perubahan Sosial. Jakarta: Prenada

The Bali Times. 2012. "Makepung Jembrana". Tesedia Pada http://www.thebalitimes.com/2012/1 0/13/jembrana-revives-makepungtradition/ (diakses tanggal 25 Februari 2014)

Wikiepedia Bahasa Indonesia, ensiklopedia bebas 2014, 17 juni, "Tradisi" tersedia pada http://id.wikipedia.org/wiki/Tradisi (diakses tanggal 25 Februari 2014)

Wikiepedia Bahasa Indonesia, ensiklopedia bebas 2014, 25 September, "Makepung" tersedia pada

http://id.wikipedia.org/wiki/Mekepun g (diakses tanggal 25 Februari 2014) 